\title{
Discrepancies between archaeological and 14C-based chronologies: problems and possible solutions
}

\author{
Hans-Christoph Strien \\ Institut für Altertumswissenschaften, Vor- und frühgeschichtliche Archäologie, Johannes Gutenberg Universität \\ Mainz, Mainz, DE \\ strien@uni-mainz.de
}

\begin{abstract}
C}$ dating of bone collagen is believed to produce the most reliable absolute dates for the Central European Early Neolithic, as the selection of bones in anatomical context minimises taphonomic problems. In contrast, a comparison of three newly published local or regional chronological models as well as a comparison of several series of dates from bone collagen, charcoal and cereals highlights problems probably caused by diagenetic influences, especially on collagen. Therefore, at least the checking of bone collagen ${ }^{14} \mathrm{C}$ dates against charcoal or cereal dates from the same contexts seems to be indispensable.
\end{abstract}

KEY WORDS - ${ }^{14} C$; taphonomy; diagenesis; Central Europe; Early Neolithic

\section{Neskladnosti med arheološkimi in ${ }^{14 C}$ kronologijami: težave in možne rešitve}

\begin{abstract}
IZVLEČEK - Za ${ }^{14} \mathrm{C}$ datiranje kostnega kolagena velja, da omogoča najbolj zanesljive absolutne datume za srednjeevropski zgodnji neolitik, saj izbor kosti iz anatomsko pravilnih kontekstov zmanjša težave s tafonomijo. V članku opozarjamo na težave, ki lahko nastanejo predvsem pri vplivu diageneza na kolagen, kar prikažemo s primerjavo treh novo objavljenih lokalnih ali regionalnih kronoloških modelov kot tudi s primerjavo številnih datumov, ki so bili pridobljeni iz kostnega kolagena, oglja in žit. Posledično opozarjamo na nujnost preverjanja ${ }^{14} \mathrm{C}$ datumov, ki so bili pridobljeni iz kostnega kolagena, $z$ datumi, pridobljenimi iz oglja ali žit iz istih kontekstov.
\end{abstract}

KLJUČNE BESEDE - ${ }^{14}$ C; tafonomija; diageneza; Srednja Evropa; zgodnji neolitik

\section{Introduction}

The starting point for some considerations concerning the reliability of ${ }^{14} \mathrm{C}$ dates are three new studies concerning the absolute chronology of the Central European early and middle Neolithic, all three of which are based mainly or entirely on dates on bone collagen. Two are from the north-western Carpathian basin (Tasic et al. 2015; Jukacs et al. 2016). The first produced an absolute chronology for the stratigraphic sequence at Vinča-Belo Brdo; the second dated the contact between Vinča A and earliest LBK (eLBK) and between Ražiste and the later LBK at Szederkény from bone collagen dates only and imbedded the results in a wider context.

The Vinča chronology poses no obvious problems. In contrast, the parallelisation of all four different ceramic styles at Szederkény, although pairwise spatially separated, contradicts the usual archaeological chronologies, postulating the (not necessarily direct) sequence Vinča A-Ražište on the one hand, and the eLBK-later LBK on the other. No explanation is given, but three much later bone dates for Ražište from 
Ivandvor are cited, without the consequences being debated. This problem will be discussed later. The site was fixed within the chronology of the Central European eLBK by using dates from varying materials, partially from dubious contexts (such as Eilsleben), some others dating from later contexts (early, but not the earliest LBK (Vedrovice, Kleinhadersdorf)). The beginning of the eLBK and its expansion is dated to about $5350 \mathrm{cal} \mathrm{BC}$. The resulting relative date - slightly earlier than Vinča A in Vinča-Belo Brdo - is not completely contrary to archaeological expectations. The 'formative phase', dated to 55005350 cal BC exclusively by charcoal, may be ignored at this point, even more so as its existence as a separate chronological unit is questionable (Strien 2017). The last study comprised bone collagen dates for the whole of the lower Alsatian Early and Middle Neolithic sequence (Denaire et al. 2017). The beginning of LBK settlement in this region was probably around $5300 \mathrm{cal} \mathrm{BC}$ or the first half of $53^{\text {rd }}$ century.

If we accept these three ${ }^{14} \mathrm{C}$-chronologies, we have to face the problem that the start of the earliest LBK in trans-Danubian Hungary dates only 50 years earlier than the start of the early LBK and the settlement of Alsace and the Rhine-Meuse region, and only 150 years earlier than the end of the early LBK (Flomborn) in the West (even taking the upper end of the $95 \%$ probability range for the end of phase IIC in Alsace). This is not so much a chronological as a demographical problem. It means that, starting from the relatively restricted area between Lake Balaton and Vienna, the whole area between the Rhine and western Ukraine was densely occupied within only 50 years. Even this time span is probably an overestimate, as on the one hand it starts with the Bína phase, which until now has not been attested outside NW Hungary and SW Slovakia, while on the other hand the earliest pits in Alsace in the correspondence analysis are not ${ }^{14} \mathrm{C}$ dated (Denaire et al. 2017.Fig. 5), so the beginning of the expansion of the eLBK may date later than $5350 \mathrm{cal} \mathrm{BC}$, and the start of the Flomborn earlier than $5300 \mathrm{cal} \mathrm{BC}$.

\section{Demographic considerations}

In south-western Germany (southern Hessen, Lower Franconia, the Neckar Valley) 200 eLBK sites are known, and 100 in Central Germany. In the Neckar Valley 194 Flomborn sites are known, but as only half of all known LBK sites are dated, we have to double this number. Even calculating with an unrealistic population growth rate of $2 \%$ per year (too high even when assuming the fast assimilation of the autochthonous hunter-gatherer population), there would have been 20 sites in the first year of eLBK expansion in order to arrive at the number of 400 sites 150 years later - one third of the number of known eLBK sites in the region - and this means 100 sites only in the above-mentioned areas of Germany. Even with a mean of 5 contemporaneous houses per site (too low in the case of sites like Vaihingen with up to 45 contemporaneous houses) and the lowest estimate of 6 inhabitants per house, this would mean that 3000 persons left the Balaton-Vienna area in the first year for south-western and central Germany, and we have to add the thousands of immigrants between Bavaria and Volhynia, an obviously unrealistic number. This calculation still ignores the additional population growth needed for the colonisation of the regions west of the Rhine only two generations after the start of the expansion, e.g., with 36 known sites in Lower Alsace at about 5250 cal BC. Even this simplified demographic estimate shows quite clearly that the three chronologies do not fit together. A start of eLBK expansion not later than $5500 \mathrm{cal} \mathrm{BC}$ would fit much better with the date of 5300 cal BC for the start of Flomborn W of the Rhine, and the date of $5350 \mathrm{cal} \mathrm{BC}$ for the start of eLBK expansion, with a start of Flomborn in Alsace not earlier than $5150 \mathrm{cal} \mathrm{BC}$. But which chronology is wrong (perhaps all of them?), and even more importantly, why? At first glance there is no evident reason to doubt any of them.

\section{Dendrochronology, ${ }^{14} \mathrm{C}$ and relative chronology}

Typological correlations with other absolute dates show that the dates for the Alsation chronology are entirely plausible. The pottery of the earliest Phase IIB is quite similar to the pottery from the Flomborn cemetery. The same holds for Vedrovice; so the start of this cemetery can be dated to immediately after the end of eLBK, where it too is placed by a new correspondence analysis of eLBK ceramic inventories (Strien 2017). The ${ }^{14} \mathrm{C}$ dates from Vedrovice suggest a start around 5300 cal BC (Pettitt, Hedges 2008), perhaps slightly earlier. So the ${ }^{14} \mathrm{C}$ age accords well with the Alsatian model. Moreover, this date is backed by dendrochronology. A well was constructed at Leipzig-Plaußig, a site with no traces of eLBK, in 5259/58 den BC (Friederich [no year].3; Herbig et al. 2013.268). Since the well has not been fixed in any relative chronology, this date can serve only as terminus ante quem for the start of the early LBK in Western Saxony. This date confirms that the early 
LBK (Flomborn) settlement of Lower Alsace as well as the Vedrovice cemetery started not later than in the first half of the $53^{\text {rd }}$ century cal BC.

The pit alignment at Herxheim can be dated with $95.4 \%$ probability somewhere in the time span $5208-$ 5053 cal BC (mean of 8 dates, calculated with Oxcal: $6161 \pm 10 \mathrm{BP}$, Haack 2015.61; this and all further calibrations done with OxCal 4.3 online). This fits quite well with the Alsatian chronology; the pits produced ceramics of late Palatinate style - phase $\mathrm{V}$ (Jeunesse et al. 2009) and respectively V/VI (Lindig 2002) - which is most probablly contemporaneous with the Lower Alsatian phases IVa2 and IVb (Lefranc 2007.Tab. 14), starting after $5185 \mathrm{cal} \mathrm{BC}$ and ending before $5020 \mathrm{cal} \mathrm{BC}(95 \%$ probability, $D e$ naire et al. 2017). And Herxheim enables a further (indirect) dendrochronological control for the ${ }^{14} \mathrm{C}$ age with the rich Šarka finds. Šarka itself is contemporaneous with the house generations (HG) XII and XIII of the Rhine-Meuse chronology, shown by imports at Elsloo (Strien 2010.502; in a new seriation (Strien, work in progress) pit 655 can be dated to HG XIII, and pit complex 653 to HG XII and XIII) and Cologne-Mengenich (Schröter 1970.Abb. 6, 10; dated to HG XII). The second well at Kückhoven, built about 5057 den BC, is dated by decorated ceramics from the destruction horizon of the first well (built in 5089 den BC) and from the construction pit, which date both very close together between HG XII and XIII. The well at Altscherbitz, built in 5099 den BC and probably filled in after a relatively short time span - along with other ceramic of the regional late LBK style - contained two pots with a pasted decoration known from Šarka contexts (Tegel et al. 2012). Together, the two wells show an age of about 5080-5030 den BC for Šarka. The ${ }^{14} \mathrm{C}$ date for Herxheim and consequently for the Alsatian phase IVb may be slightly too old, but the $95 \%$ range of both at least overlaps with the date interpolated from dendrochronology and typochronology, so we should accept the Alsatian ${ }^{14} \mathrm{C}$ chronology at least as a good approximation for the both start and the end of the dated part of the Lower Alsace LBK sequence, with only phase $\mathrm{V}$ remaining undated.

The same cannot be said for the start of the Middle Neolithic sequence; a date in the $48^{\text {th }}$ century for Hinkelstein is clearly too late, probably by about 200 years. Most chronologies based on typology published in the last 30 years postulate at least an overlap between Hinkelstein and late western LBK, often even a similar end date for both (e.g., Jeunesse, Strien 2009; Spatz 1996; Lefranc 2007; Stehli
1994). Sometimes a gradual succession LBK/Hinkelstein can be mapped (Strien 2013). This is confirmed beyond doubt by the sequence of Šarka/early Stroked Pottery Culture (SBK) in the East, demonstrated at the household level at Dresden-Prohlis (Link 2014); Šarka being contemporaneous with late, but not the latest western LBK, and SBK II/III with Hinkelstein, no time is left for a gap between the LBK and Hinkelstein in the West. This may be the case on a regional scale, but not generally, and not to the extent of up to two centuries.

A closer look at some local series may shed light on the question. Differences between dates from charcoal, cereals and bone collagen can regularly be seen, with dates on bone usually being the youngest group. Even a simple comparison of unweighted means of uncalibrated dates shows this effect quite clearly:

- Rottenburg: cereals (2 dates) $6155 \mathrm{BP}$, bone (12 dates) 5965 BP (Bofinger 2005.112-120, Tab. 15) - difference 190 years (cereals/bone);

- Bruchenbrücken (only dates earlier than 5900 BP in order to exclude late LBK intrusions; Stäuble 2005. Anhang D): cereals ( 4 dates) $6215 \mathrm{BP}$, charcoal (3 dates) $6377 \mathrm{BP}$, bone (4 dates) $6144 \mathrm{BP}$ difference 233 years (charcoal/bone) resp. 71 years (cereals/bone). Only if all dates later than $6200 \mathrm{BP}$ were excluded, the differences would for the most part disappear, but in this case, the whole bone collagen series from Strögen has to be rejected;

- Strögen pit 5 (Lenneis, Lüning 2001): cereals (1 date) $6506 \mathrm{BP}$, charcoal (2 dates) $6313 \mathrm{BP}$, bone (4 dates; VERA-896 excluded as an outlier) 6152 $\mathrm{BP}$ - 161 years (charcoal/bone) resp. 354 years (cereals/bone);

- Schwanfeld (Stäuble 2005.Anhang D; only dates earlier than $5900 \mathrm{BP}$ in order to exclude late LBK intrusions and only dates with a standard deviation of $\leq 100$ years): cereals ( 1 date) $6380 \mathrm{BP}$, charcoal (3 dates) $6493 \mathrm{BP}$, bone (3 dates) $6321 \mathrm{BP}-$ 172 years (charcoal/bone) resp. 59 years (cereals/ bone).

A systematic deviation of bone collagen dates to a younger age is clearly visible; even if there were an overlap between the $95.4 \%$ ranges of floral and faunal dates (which is often but not always the case, Fig. 1) for each single site, any kind of group calibration would produce a later age for the bone collagen series. 
The Middle Neolithic series from Western Germany show the same effect, resulting in a systematic difference between the Lower Rhine area (only charcoal dates) and SW Germany (mainly bone dates; Friederich 2011.Tab. 89-90), resulting in a strange chronology: the Middle Neolithic in SW Germany starts with Hinkelstein and in Rhenania only slightly later with late (!) Großgartach. The complete GroßgartachPlanig-Friedberg-Rössen-Bischheim sequence, present in both regions, should be delayed in SW Germany by at least 150 years, but follow the same stylistic development in both regions (Friederich 2011.397406, Fig. 347). Here the ${ }^{14} \mathrm{C}-$ based chronology evidently contradicts the archaeological facts and each plausible reconstruction of cultural history, and it does not become much better by the third, Alsatian chronology for the same time span (Fig. 2).

A special case is the eLBK site at Rottenburg (Bofinger 2005). The two dates on cereals and the two earliest dates on bone - both identified as outliers from the rest - are in a range one can argue as perhaps correct (although more probably too young, the lower limit of the $95.4 \%$ probability range being $5290 \mathrm{cal} \mathrm{BC}$ for the cereals, and $5305 \mathrm{cal} \mathrm{BC}$ for the bones), the 10 remaining bone dates are five to six centuries too young, 4846-4722 cal BC $(95.4 \%$ range) - almost exactly the assumed time span for Hinkelstein in Alsace, which is thought to be too late. The context is quite clear: the bones came from the long pits of the houses, below the preserved lower part of the original soil horizon. On top was a layer mixed from the disturbed upper part of the soil and material that went down the hill slope, dated to the late pre-Roman period, and a Roman road (Kind 2005.255-262, Fig. 1-5: units 4 and 3). In this layer, only three small sherds with eroded surfaces of late LBK/Hinkelstein date were identified (along with much more eLBK material and some Roman pieces; data: own analysis), the other, Neolithic, sherds, almost 18000 of them, most from the layers below, are all eLBK (or La Hoguette), as far as can be recognised. So there can be no reasonable doubt that the dated bones belong to the eLBK sherds.

The last example is the Hinkelstein and Großgartach cemetery at Trebur (Spatz 1999.213-217). Here we see a difference even between conventional and AMS dates on bone collagen. One outlier excluded nine graves are dated with both methods. The mean difference between the uncalibrated dates is 134 years, with the AMS dates in all nine cases being earlier. Nevertheless, even the AMS dates are considered to be too late (Spatz 1999.216-217).

Observations like these are far from new, and only confirm earlier results (Denaire 2009). A difference of 160-230 years (uncalibrated) cannot be explained only by the old-wood effect - even the trunk of a 300-year-old oak consists mainly of wood younger than 200 years, not to speak of the branches. This is shown, too, by the dates on cereals from the abovementioned eLBK sites, which are clearly older than the dates on bone from the same sites. And finally, the old wiggle matching calibration of charcoal dates from Merzbach valley fits quite well with the Alsatian chronology, with a start of Flomborn at around 5300 cal BC (Stehli 1989). These dates from the 1970s are not very reliable, but at least they do not show any important old wood effect, compared to the Alsatian dates on bone collagen. When bone dates accord with dendrochronologically controlled age, there seems to be no serious difference to charcoal dates.

\section{Too young, but sometimes too old: the case of Ražište/Sopot IB-II}

A look at the Carpathian basin shows that there are rare cases when bone collagen dates are too old. Starting with Ivandvor, a Sopot IB-II/Ražiste-site with the usual pattern (dates from Jakucs et al. 2016):

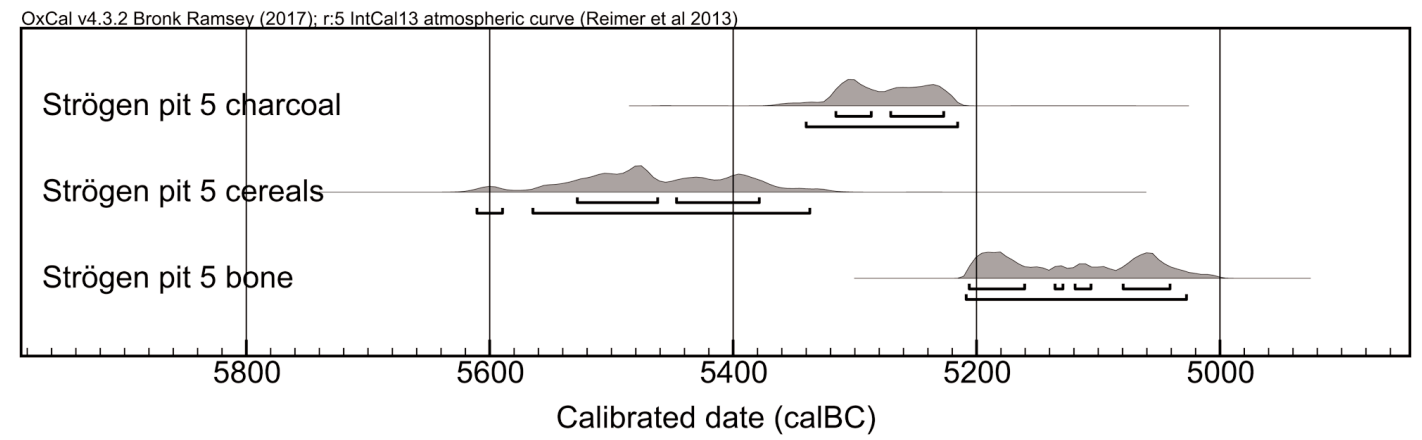

Fig. 1. Comparison of calibrated ages of charcoal (two dates), cereals (one date), and bone collagen (four dates) from Strögen pit 5. 
charcoal (3 dates) $5947 \mathrm{BP}$, bone (3 dates) $5717 \mathrm{BP}-230$ years older date for charcoal. These dates are not only contradictory in themselves, but do not fit with other ${ }^{14} \mathrm{C}$ series for the Ražište/Sopot IB-II context: the site was dated by János Jakucs et al. (2016.35) to "the second quarter of the fifth millennium". The Sopot graveyard at Alsónyék is dated somewhere between 5200-5020 cal BC (95\% probability for the beginning) and $4850-4680$ cal BC (95\% probability for the end) (Oross et al. 2016.166), so it dates mainly to the first quarter of the fifth millennium. At Szederkenyi, Ražište is dated "between the $54^{\text {th }}$ and $52^{\text {nd }}$ centuries cal BC" (Jakucs et al. 2016.32).

If all these series are accepted, Sopot IB-II - usually taken as transitional between LBK and Lengyel (Oross et al. 2016. 151152) and synchronised with late LBK (Šarka) and early SBK in Bohemia (overview in Gleser 2012) - would span more than 600 years, ranging from the start of eLBK expansion, about 5350-

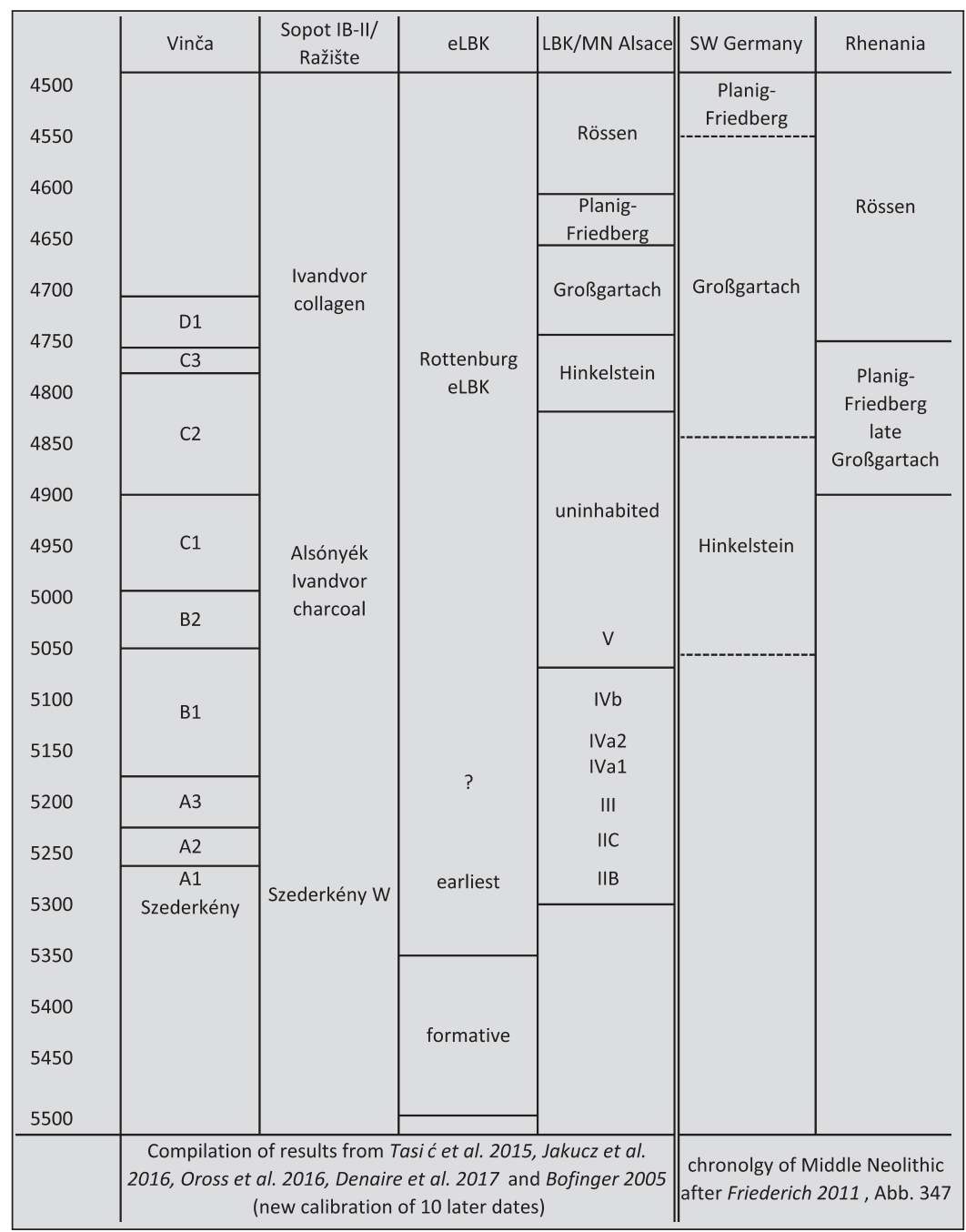

Fig. 2. Chronological table 5500-4500 cal BC, based on ${ }^{14} \mathrm{C}$.
$5300 \mathrm{cal} \mathrm{BC}$, at least until $4700 \mathrm{cal} \mathrm{BC}$ or even later, far beyond the latest estimate for the end of late LBK. On the one hand Sopot IB-II is connected typochronologically to Vinča C1 (phase 6 at Vinča-Belo Brdo; Oross et al. 2016.158-159) - dated somewhere between 5040 and 4855 cal BC (Tasić et al. 2016. Tab. 8), almost exactly the minimum time span given for Alsónyék - and on the other hand at Szederkény by ${ }^{14} \mathrm{C}$ to Vinča $\mathrm{A} 1$ resp. A1-A3, although without much contact between the two groups except for some isolated Ražište sherds in Vinča context, but not vice versa (Jakucs et al. 2016.30), which makes later intrusions more probable than contact. In addition, Ražište is associated with later LBK, and Vinča A with eLBK. So there are archaeological arguments that clearly contradict the very early dates from Szederkény, and no other ${ }^{14} \mathrm{C}$ dates support them, as the authors admit (Jakucs et al. 2016. 35). The dates on charcoal from Ivandvor seem to match with archaeology, the two dates from feature SU 407 dating to 5021-4842 cal BC (95.4\%) - the minimum range for Alsónyék - and the single date from feature SU 194 to $4766-4499$ cal BC, slightly too late. A date about or shortly after $5000 \mathrm{BC}$ is most plausible, comparing relative chronology (Šarka/early SBK) with dendrochronology (Šarka dating around 5050 den BC, as shown above). So we have two sets of dates (Alsónyék, Ivandvor charcoal) that fit with a dendrochronological age derived from relative chronology, as well as with a ${ }^{14} \mathrm{C}$ series from a site with the same relative age (Vinča-Belo Brdo), one set much too old (Szederkény) and one too late (Ivandvor bone collagen).

\section{Why bone collagen?}

In the three series with very large differences from expected date - Rottenburg, the Aisne Valley and Trebur (conventional dates) - the common element is geology: all these sites are located on fluviatile sediments, with either thin or no loess coverage. We can even add two more examples. At Ulm-Eggingen 
(sited on tertiary sands with a thin loess coverage), the charcoal dates (Dombek 1989) are clearly too young: house 12 , archaeologically dated shortly after the end of Flomborn, and so some generations earlier than the Kückhoven wells, was dated in the range 4946-4743 cal BC (95.4\% probability, one outlier excluded), and the waterlogged wood from the Mohelnice well, with a questionable dendrochronological date around 5600 den $\mathrm{BC}$, but in any case not later than 5400 den BC (Schmidt, Gruhle 2003.56), dated to $5364-5007$ cal BC $(99.7 \%$ range; 3 dates from Neustupny, Vesely 1977). The possibility of hydrogeological influences on the diagenesis of charred and uncharred organic matter, especially bone collagen, should be taken into consideration. The difference between conventional and AMS dates from Trebur strengthens this idea, as later contaminations had probably been removed much better from material for the AMS dates than from the bigger pieces for conventional dates (Spatz 1999.217). It is further reinforced by a fourth date from the Mohelnice well

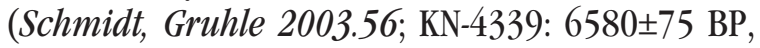
not included in the data list by Jakucs et al. 2016), which has an uncalibrated age $300{ }^{14} \mathrm{C}$-years older

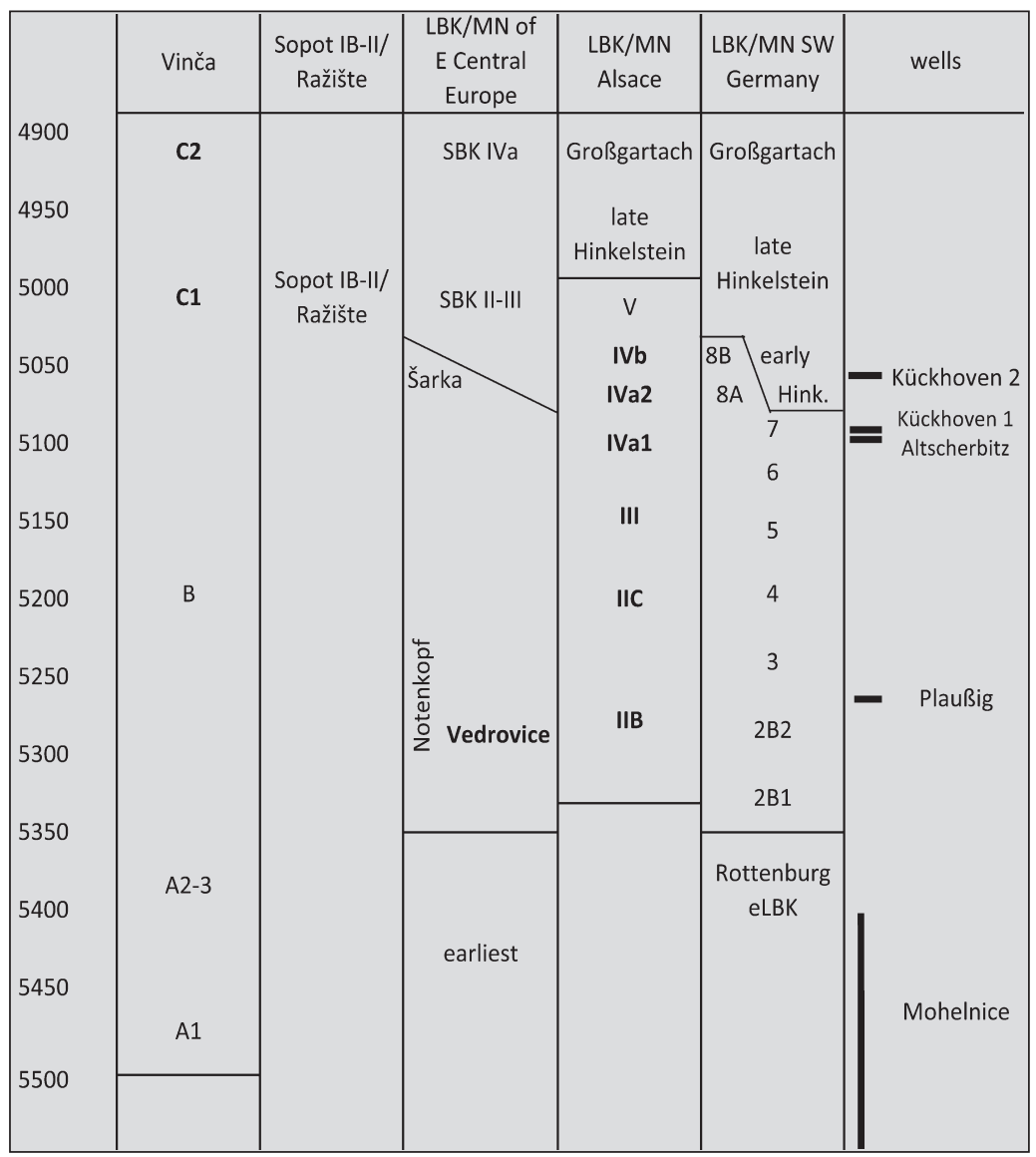

Fig. 3. Chronological table 5500-4900 BC, based on relative chronologies, archaeological correlations and dendrochronologically dated wells. In bold: date in accordance with ${ }^{14} \mathrm{C}$ age. than the mean of the other dates. It is the only one that fits with the dendrochronological age $(87.7 \%$ probability: $5641-5461 \mathrm{cal} \mathrm{BC,} 7.7 \%$ : 5451-5377 cal $\mathrm{BC})$, so we may assume that for this sample the removal of contaminations was much more successful than for the samples dated in the 1970s, and that contamination by water may play an important role even in an undisturbed context.

Szederkény is an interesting case. The dates for the eastern and central part of the site with Vinča $A$ and eLBK ceramics are probably too young. The dates for the western part with Ražište and later LBK finds, on the other hand, are clearly too old as shown above. So far, this is the only case in which the bone dates are too old. Here we possibly see different diagenetic influences on bone collagen in parts of the same site separated by a distance of little more than $100 \mathrm{~m}$. A closer look at geological and hydrological properties of the different parts of the site might teach us something about the nature of the diagenetic processes involved. Apart from hydrogeological factors, no other reasons are clearly visible. But as there seem to be regional as well as local differences, it is not very probable that only one factor lies behind the problem. If it is really hydrology, we may even assume the possibility that the lowest levels of a tell near to groundwater level - are affected, whereas the upper layers yield correct dates. The start of Vinča-Belo Brdo might be dated too late, and the later phases from Vinča B or C onwards might not (at least the date for $\mathrm{C} 1$ corresponds to the expected date; Fig. 3).

We may conclude that dates on bone collagen are often too young, but not in every case; the best examples of series that accord with other dates are the Alsatian LBK and Rössen to Epirössen sequences. Compared with the Alsatian chronology, the same holds for the Vedrovice cemetery and the pit alignment at Herxheim. Most other bone collagen series from the Central European Neolithic in the second half of the $6^{\text {th }}$ and the $5^{\text {th }}$ millennia $\mathrm{BC}$ are too young, in individual cases even up to 500 years. 


\section{How to solve the problem}

Of course, a large-scale study on causes and possible remedies is not only desirable, but even necessary. As long as this study is lacking, we have to look for ways to minimise the risks. The first step is that dates on collagen must always be checked against charcoal or cereal dates from the same context; financial constraints concerning the number of dates are not an excuse for methodological deficits. In the case of differences of more than 50 BP-years between dates from faunal and floral carbon, the bone dates at least should be questioned, if not rejected. From a purely taphonomic point of view, dates from bones in anatomical contact are the best choice, but in the case of settlement pits, it may be preferable to use botanic material for ${ }^{14} \mathrm{C}$ dating, making taphonomic problems improbable by taking three or more samples from different depths of a column. The higher cost of dating more samples is the price for the time saved collecting the samples compared to the time-consuming identification of bones in anatomical contexts and make misleading results caused by diagenetic processes less probable, without excluding them, as shown by the examples of Ulm-Eggingen and, probably, Rottenburg.

\section{Archaeology first}

Finally, this paper shows that even the most refined, technically advanced methods used by the natural sciences can provide only an additional source of information. Our subject being archaeology, we always have to check the external data to see whether they fit with our archaeological data, and if not, why not. In the last few years there has been a tendency towards an unfounded reliance on ${ }^{14} \mathrm{C}$ dating alone, culminating in the conclusion concerning the four late and ten extremely late dates from Rottenburg: "presumably there is a so-far unresolved problem with the detection of later activity" (Jakucs et al. 2016.53), thus a priori excluding any problem with the dates themselves. As Rottenburg is probably the site with the best preservation of all known eLBK sites, with an unbroken layer of eLBK sherds above the ${ }^{14} \mathrm{C}$-dated pits (Kind 2005.Abb. 3-5), thoroughly excavated and documented by an experienced excavator, this shows an impressingly uncritical attitude towards ${ }^{14} \mathrm{C}$ and distrust in archaeology. Scientific measurements and statistical analyses of them are not necessarily more reliable or accurate than our own methods, even if they are sometimes assumed to achieve a level of obvious pseudo-accuracy, as in the conclusions on Hinkelstein in Alsace: "the appear- ance of Hinkelstein ceramics in Alsace was swift: taking 1-115 years (95\% probability...)"; "Hinkelstein ceramics were probably used in this area for one or two generations" (Denaire et al. 2017.43); and "the re-establishment of ways of doing things may have been quite rapid (1-40 years at 68\% probability)" (Denaire et al. 2017.71) - conclusions derived from two graves and one pit included in a seriation, only the two graves being dated by ${ }^{14} \mathrm{C}$. How can we get any useful information about time spans and rapid or slow developments from a data base such as this; from a data base which was not checked to ascertain whether the suspected problems with collagen dates (Denaire 2009) were real, but enriched by two dates from a site almost $150 \mathrm{~km}$ away, in another region with a longer duration of Hinkelstein occupation? Calculations like these may be statistically satisfying, but nothing more. The results cannot be the reliable approach to prehistoric reality that should be the aim of our research.

Of course, we may assume that the dates from Vinča and the Hungarian sites (and consequently also those from the early middle Neolithic in Alsace and SW Germany) are correct, shifting the whole sequence by 150-200 years; however, in this case, the LBK and Rössen series from Alsace would be too old, and even worse, the dendrochronological dates from the wells would not fit with the ${ }^{14} \mathrm{C}$ chronology. And how should we explain a series like Rottenburg? A model that assumes they are all correct (Fig. 2) is completely incompatible with relative chronology (Fig. 3). A serious problem at least with some of the ${ }^{14} \mathrm{C}$ dates on bone collagen has to be admitted - or a completely new chronological system has to be constructed, with, for example, eLBK lasting for six centuries (5350-4750 cal BC), ending at about the same time as Hinkelstein, as we have no evident reason to discard the dates from Rottenburg while accepting the Ražište dates from Szederkény.

In the light of these results, the 'formative phase' of eLBK in Transdanubia must be reconsidered: the difference of about 150 years between its beginning and the start of the rest of the eLBK might be explained by the different material used for ${ }^{14} \mathrm{C}$ dating. Looking from the West, a date about $5500 \mathrm{cal} \mathrm{BC}$ for the beginning of eLBK expansion seems to be more reliable, while the date of $5350 \mathrm{cal} \mathrm{BC}$ based on bone collagen dates is about 150 years too young. Interpreting the 'formative phase' as a regional variant of the eLBK and not as its predecessor - as supposed by typological maps and the results of a correspondence analysis of some 600 features of eLBK 
and the intial Flomborn/Notenkopf phases (Strien 2017 ) - both starting at $5500 \mathrm{cal} \mathrm{BC}$, would avoid the demographic problems connected with the late date for the expansion horizon. If this model were accepted, the start date for Vinča-Belo at least Brdo would also be too young.

What becomes evident in this context is the lack in SE Central Europe of any modern typochronology based not only on a clearly defined typology, but also on appropriate statistical instruments. So far, for the whole area between Bylany and Vinča-Belo Brdo no modern chronology has been published that covers at least a major part of the time span between the start of the LBK and the transition to its successors. The establishment of fine-grained regional typological chronologies and their interregional correlation using classical analyses of foreign forms and importations as well as modern statistical methods (e.g., Procustes analysis of seriations) and additional information like the demographic considerations discussed above, correlated with precise absolute dates from the wells, may and should be supported, but can in no way be replaced by ${ }^{14} \mathrm{C}$ dating. Radiocarbon dating is not the Holy Grail of prehistoric archaeology, especially as long as environmental influences on its results are neither fully recognised nor understood.

\section{References}

Bofinger J. 2005. Untersuchungen zur neolithischen Besiedlungsgeschichte des Oberen Gäus. Materialhefte zur Archäologie in Baden-Württemberg 68. Konrad Theiss Verlag. Stuttgart.

Denaire A. 2009. Radiocarbon dating of the western European Neolithic: comparison of the dates on bones and dates on charcoals. Radiocarbon 51(2): 657-674.

Denaire A., Lefranc Ph., Wahl J., Bronk Ramsey C., Dunbar E., Goslar T., Bayliss A., Beavan N., Bickle P. and Whittle A. 2017. The cultural project: formal chronological modelling of the early and middle Neolithic sequence in Lower Alsace. Journal of Archaelogical Method and Theory 24 (4): 1072-1149. doi 10.1007/s10816-016-9307-x

Dombek G. 1989. Die ${ }^{14 C-D a t e n ~ v o n ~ U l m-E g g i n g e n . ~ I n ~ C .-~}$ J. Kind, Ulm-Eggingen. Bandkeramische Siedlung und mittelalterliche Wüstung. Konrad Theiss Verlag. Stuttgart: 401-412.

Friederich S. 2011. Bad Friedrichshall-Kochendorf und Heilbronn-Neckargartach. Forschungen und Berichte zur Vor- und Frühgeschichte in Baden-Württemberg 123. Konrad Theiss Verlag. Stuttgart.

(no year). Archäologische Ausgrabungen. Bandkeramischer Brunnen, Leipzig-Plaußig. www.archaeologie. sachsen.de/download/II_22_plauss_02.pdf

Gleser R. 2012. Zeitskalen, stilistische Tendenzen und Regionalität des 5. Jahrtausends in den Altsiedellandschaften zwischen Mosel und Morava. In R. Gleser, V. Becker (eds.), Mitteleuropa im 5. Jahrtausend vor Christus. Beiträge zur internationalen Konferenz in Münster 2010. Neolithi- kum und ältere Metallzeiten. Studien und Materialien Bd. 1. Lit Verlag Dr. W. Hopf. Berlin: 35-103.

Haack F. 2016. Die frühneolithische Grabenanlage von Herxheim bei Landau: Architektur, Verfüllungsprozesse und Nutzungsdauer. www.diss.fu-berlin.de/diss/receive/ FUDISS_thesis_000000102455

Herbig C., Maier U., Stäuble H. and Elburg R. 2013. 'Neolithische Füllhörner'. Archäobotanische Untersuchungen in fünf linienbandkeramischen Brunnen in Westsachsen. offa 69/70: 265-293.

Jeunesse C., Lefranc Ph. and van Willigen S. 2009. Die pfälzische Bandkeramik: Definition und Periodisierung einer neuen Regionalgruppe der Linearbandkeramik. In A. Zeeb-Lanz (ed.), Krisen-Kulturwandel-Kontinuitäten. Zum Ende der Bandkeramik in Mitteleuropa. Beiträge der Internationalen Tagung in Herxheim bei Landau (Pfalz) vom 14.-17.06.2007. Internationale Archäologie. Arbeitsgemeinschaft, Symposium, Tagung, Kongress 10. Verlag Marie Leidorf GmbH. Rahden/Westf.: 61-77.

Jeunesse C., Strien H.-C. 2009. Bemerkungen zu den stichbandkeramischen Elementen in Hinkelstein. In A. ZeebLanz (ed.), Krisen-Kulturwandel-Kontinuitäten. Zum Ende der Bandkeramik in Mitteleuropa. Beiträge der Internationalen Tagung in Herxheim bei Landau (Pfalz) vom 14.-17.06.2007. Internationale Archäologie. Arbeitsgemeinschaft, Symposium, Tagung, Kongress 10 10. Verlag Marie Leidorf GmbH. Rahden/Westf.: 241-248

Jakucs J., Bánffy E., Oross K., Voicsek V., Bronk Ramsey C., Dunbar E., Kromer B., Bayliss A. Hofmann D., Marshall P. and Whittle A. 2016. Between the Vinča and Linearband- 
keramik Worlds: The Diversity of Practices and Identities in the $54^{\text {th }}-53^{\text {rd }}$ Centuries cal BC in Southwest Hungary and beyond. Journal of World Prehistory 29(3): 267336. doi 10.1007/s10963-016-9096-x

Kind C.-J. 2005. Stratigraphie und Steinartefakte der Siedlung der Ältesten Bandkeramik von Rottenburg ,Fröbelweg'. In J. Bofinger, Untersuchungen zur neolithischen Besiedlungsgeschichte des Oberen Gäus. Materialhefte zur Archäologie in Baden-Württemberg 68. Konrad Theiss Verlag. Stuttgart: 255-322.

Lefranc Ph. 2007. La céramique du Rubané en Alsace: contribution à l'étude des groups régionaux du Néolithique ancient dans la plaine du Rhin supérieur. Monographies d'Archéologie du Grand-Est - Rhin, Meuse, Moselle 2. Université Marc Bloch. Strasbourg.

Lenneis E., Lüning J. 2001. Die altbandkeramischen Siedlungen von Neckenmarkt und Strögen. Universitätsforschungen zur Prähistorischen Archäologie 82. Verlag Dr. Rudolf Habelt GmbH. Bonn.

Lindig S. 2002. Das Früh- und Mittelneolithikum im Neckarmündungsgebiet. Universitätsforschungen zur Prähistorischen Archäologie 85. Verlag Dr. Rudolf Habelt GmbH. Bonn.

Link T. 2014. Die linien- und stichbandkeramische Siedlung von Dresden-Prohlis. Eine Fallstudie zum Kulturwandel in der Region der oberen Elbe um 5000 v.Chr. Veröffentlichungen des Landesamtes für Archäologie Sachsen Bd. 60. Landesamt für Archäologie. Dresden.

Neustupný E. F., Vesely K. 1977. Most radiocarbon dates I. Radiocarbon 19(2): 183-187.

Oross K., Osztás A., Marton T., Köhler K., Ódor J. G., Széczényi-Nagy A., Bánffy E., Alt K. W., Bronk Ramsey C., Kromer B., Bayliss A., Hamilton D. and Whittle A. 2016. Midlife changes: the Sopot burial ground at Alsónyék. Bericht der Römisch-Germanischen Kommission 94: 151-178.

Pettitt P., Hedges R. 2008. The age of the Vedrovice cemetery: the AMS radiocarbon dating programme. Anthropologie XLVI(2-3): 125-134.

Schmidt B., Gruhle W. 2003. Wuchshomogenität als ein neues Analyseverfahren zur Verbesserung der dendrochronologischen Datierungsmethode. Die Hölzer der neolithischen Brunnen von Erkelenz-Kückhoven, Zwenkau und Mohelnice sowie vom Fundplatz Kaster. In J. Eckert, U. Eisenhauer and A. Zimmermann (eds.), Archäologische Perspektiven. Analysen und Interpretationen im Wandel. Festschrift für Jens Lüning zum 65. Geburtstag. Internationale Archäologie Studia Honoraria 2. Verlag Marie Leidorf GmbH. Rahden/Westf.: 49-60.
Schröter I. 1970. Die bandkeramische Siedlung von KölnMengenich. Kölner Jahrbuch 11: 37-47.

Spatz H. 1996. Beiträge zum Kulturenkomplex Hinkelstein - Großgartach - Rössen. Materialhefte zur Archäologie in Baden-Württemberg 37. Konrad Theiss Verlag. Stuttgart.

1999. Das mittelneolithische Gräberfeld von Trebur, Kreis Groß-Gerau. Materialien zur Vor- und Frühgeschichte von Hessen 19. Landesamt für Denkmalpflege. Wiesbaden.

Stäuble H. 2005. Häuser und absolute Datierung der Ältesten Bandkeramik. Universitätsforschungen zur Prähistorischen Archäologie 117. Verlag Dr. Rudolf Habelt GmbH. Bonn.

Stehli P. 1989. Zur relativen und absoluten Chronologie der Band-keramik in Mitteleuropa. In J. Rulf (ed.), Bylany Seminar 1987. Collected Papers. Arheologický ústav Československe akademie věd. Prague: 69-78.

1994. Chronologie der Bandkeramik im Merzbachtal. In J. Lüning, P. Stehli (eds.), Die Bandkeramik im Merzbachtal auf der Aldenhovener Platte. Beiträge zur neolithischen Besiedlung auf der Aldenhovener Platte 5. Rheinische Ausgrabungen 36. Rheinland Verlag GmbH: 79-192.

Strien H.-C. 2010. Mobilität in bandkeramischer Zeit. In D. Gronenborn, J. Petrasch (eds.), Die Neolithisierung Mitteleuropas. Internationale Tagung, Mainz 24. bis 26. Juni 2005. Römisch-Germanische Zentralmuseum Tagungen Bd. 4. Mainz: 497-508.

2013. Besiedlungsgeschichte des Zabergäus 5500-5000 v. Chr. In C. Schenk, P. Wanner (eds.), Heilbronnica 5. Beiträge zur Stadt- und Regionalgeschichte. Stadtarchiv Heilbronn. Heilbronn: 35-50.

2017. Westexpansion und Regionalisierung der ältesten Bandkeramik. Welt und Erde. Kerpen-Loogh.

Tasić N., Marić M., Bronk Ramsey C., Kromer B., Barclay A., Bayliss A., Beavan N., Gaydarska B. and Whittle A. 2015. Vinča-Belo Brdo, Serbia: The times of a tell. Germania 93: $1-75$.

Tegel W., Elburg R., Hakelberg D., Stäuble H. and Büntgen U. 2012. Early Neolithic Water Wells Reveal the World's Oldest Wood Architecture. PLOS ONE 7(12): e51374. doi: 10.1371/journal.pone.0051374

Wild E. M., Stadler P., Häußer A., Kutschera W., Steier P., Teschler-Nicola M., Wahl J. and Windl H. J. 2004. Neolithic massacres: local skirmishes or general warfare in $\mathrm{Eu}-$ rope? Radiocarbon 46(1): 377-385. 